\title{
Pseudomonas monteilii sp. nov., Isolated from Clinical Specimens
}

\author{
MALIKA ELOMARI, LOÏC COROLER, SOPHIE VERHILLE, \\ DANIEL IZARD, AND HENRI LECLERC*
}

\author{
Laboratoire de Bacteriologie Hygiène, Faculté de Médecine Henri Warembourg, 59045 Lille Cedex, France
}

\begin{abstract}
We propose the name Pseudomonas monteilii for a new species of gram-negative, rod-shaped, motile bacteria that were nonhemolytic on blood agar and were isolated from clinical sources. The 10 strains of $P$. monteilii were incapable of liquefing gelatin. They grew at $10^{\circ} \mathrm{C}$ but not at $41^{\circ} \mathrm{C}$, produced fluorescent pigments, catalase, and cytochrome oxidase, and possessed the arginine dihydrolase system. They were capable of respiratory but not fermentative metabolism. They did not hydrolyze esculin or starch and were able to use benzylamine, $\alpha$ aminobutyrate, $D$-ribose, $L$-arabinose, butyrate, valerate, isovalerate, isobutyrate, inositol, phenylacetate, $D$-alanine, and amylamine. They possessed L-phenylalanine arylamidase, L-lysine arylamidase, L-alanine arylamidase, $\gamma$-glutamyl-transferase, glycyl-phenylalanine arylamidase, L-tryptophan arylamidase, glycyl-L-alanine arylamidase, esterase $C_{4}$, esterase $C_{6}$, esterase $C_{8}$, esterase $C_{9}$, esterase $C_{10}$, and esterase $C_{18}$. DNA relatedness studies revealed that $\boldsymbol{P}$. monteilii strains formed a homogeneous DNA hybridization group. A total of 57 strains representing previously described or partially characterized taxa belonging to the genus Pseudomonas were 6 to $54 \%$ related to $P$. monteilii. The highest hybridization values were obtained with strains belonging to or related to $P$ seudomonas putida biovar $A$. The average $G+C$ content of the DNA was $60.5 \pm 0.5 \mathrm{~mol} \%$ for four of the $P$. monteilii strains studied. The type strain of $P$. monteilii is CFML 90-60 (= CIP 104883); it was isolated from bronchial aspirate and has a $\mathrm{G}+\mathrm{C}$ content of $60 \mathrm{~mol} \%$. The clinical significance of these organisms is not known.
\end{abstract}

It is generally accepted today that the genus Pseudomonas, as described in Bergey's Manual of Systematic Bacteriology (32), was multigeneric and should not be maintained as a single genus $(11-13,33,34,53,60,61)$. The taxonomy of this genus is based mainly on the phenotypic characterization carried out by Stanier et al. (51) and the groups proposed by Palleroni et al. (38) on the basis of rRNA-DNA hybridization studies. Recent studies on pseudomonads have clarified their taxonomy (35) and have led to the creation of new genera, such as the genera Stenotrophomonas (36), Comamonas (54), Acidovorax (59), Hydrogenophaga (60), Sphingomonas (62), Burkholderia (64), Ralstonia (63), Telluria (4), and Brevundimonas (47). Therefore, the genus Pseudomonas sensu stricto should be restricted to Pseudomonas rRNA group I $(12,32)$, which includes both fluorescent and nonfluorescent species (Pseudomonas stutzeri $[37,56]$, Pseudomonas mendocina, Pseudomonas alcaligenes [42], and Pseudomonas fragi [30]).

Pseudomonas aeruginosa, Pseudomonas fluorescens, Pseudomonas putida, Pseudomonas chlororaphis (5, 23, 39, 51), and the plant-pathogenic Pseudomonas species (Pseudomonas syringae and Pseudomonas cichorii) are the most important fluorescent species (34). Two other species, Pseudomonas veronii (16) and Pseudomonas rhodesiae (6), have been described recently for fluorescent Pseudomonas strains isolated from natural mineral waters (15). A common characteristic of all of the above organisms is the production of pigments that fluoresce under short-wavelength UV light (25). Taxonomically, the fluorescent pseudomonads are extremely complex. The plantpathogenic fluorescent pseudomonads $(17,32)$ are characterized by a negative arginine dihydrolase reaction and represent a branch that is phylogenetically separate from the other fluorescent organisms in similarity group I of Palleroni (32).

* Corresponding author. Mailing address: Laboratoire de Bacteriologie Hygiène, Faculté de Médecine Henri, Warembourg, 1 place de Verdun, 59045 Lille Cedex, France. Phone: (33) 03204445 97. Fax: (33) 032052 93 61. E-mail: leclerc@univ-lille2.fr.
$P$. aeruginosa, the type species of the genus Pseudomonas, is a typical opportunistic pathogen (3). Most strains of this species can be easily identified by a number of phenotypic characteristics (34). This is a homogeneous species on genotypic grounds (35).

$P$. fluorescens and $P$. putida were described a few years after $P$. aeruginosa was described. $P$. putida is particularly interesting. Recently, on the basis of a lot of research, workers have described a role for $P$. putida in aromatic hydrocarbon degradation $(21,24,26,27,31,40,46,48)$. Moreover, strains of $P$. putida are very common environmental contaminants, as mentioned by Hugh and Gilardi (22), and this organism is rarely pathogenic for humans, even though it has been found associated with urinary tract infections, septicemia, septic arthritis, osteomyelitis, wound infections, pelvic inflammatory disease, and various other diseases (33). In any event, although its virulence may be low, $P$. putida should be considered potentially pathogenic (58). There are numerous references to isolation from a variety of materials of clinical origin in the literature $(2,18,19,41,43,52,57)$.

In 1994, we showed on the basis of a numerical analysis (14) of the phenotypic characteristics of 39 strains that there are four phenotypic subclusters (subclusters IIa to IId) among strains of clinical origin that belonging to or are related to $P$. putida. Subcluster IIb included collection strains and the type strain of $P$. putida biovar A, whereas subclusters IIa, IIc, and IId contained only wild strains. The purpose of this study was to determine the taxonomic position of subcluster IIc by using genotypic methods (DNA-DNA hybridization and the difference between the melting point of a heteroduplex and the melting point of a homoduplex $\left.\left[\Delta T_{m}\right]\right)$. Here we formally describe a new species, $P$. monteilii, whose type strain is CFML 90-60 (= CIP 104883).

\section{MATERIALS AND METHODS}

Bacterial strains. A total of 92 strains were studied. These organisms included 35 wild strains that were isolated from clinical specimens (Table 1) (14) and were received as $P$. putida. These strains were collected during two years (1987 and 
TABLE 1. Strains used and levels of relative binding of DNAs from members of Pseudomonas section I and V species to $\left[{ }^{3} \mathrm{H}\right] \mathrm{DNA}$ from $P$. monteilii CFML $90-60^{\mathrm{T}}$

\begin{tabular}{|c|c|c|c|c|}
\hline \multirow{2}{*}{$\begin{array}{l}\text { Taxon (as received) } \\
\text { or phenotypic } \\
\text { subcluster }\end{array}$} & \multirow{2}{*}{ Strain $^{a}$} & \multicolumn{2}{|c|}{$\begin{array}{l}\text { Labeled DNA from } \\
\text { strain CFML } 90-60^{\mathrm{T}}\end{array}$} & \multirow{2}{*}{$\begin{array}{l}\mathrm{G}+\mathrm{C} \\
\text { content } \\
(\mathrm{mol} \%)\end{array}$} \\
\hline & & $\begin{array}{l}\text { Relative binding } \\
\text { ratio }(\%)\end{array}$ & $\begin{array}{l}\Delta T_{m} \\
\left({ }^{\circ} \mathrm{C}\right)\end{array}$ & \\
\hline \multirow[t]{10}{*}{ Subcluster IIc } & CFML $90-60^{\mathrm{T}}$ & 100 & 0.0 & 60 \\
\hline & CFML 90-56 & 99 & & 61 \\
\hline & CFML 90-58 & 95 & & \\
\hline & CFML 90-62 & 94 & & \\
\hline & CFML $90-54$ & 94 & & 60.5 \\
\hline & CFML 90-61 & 93 & & 60 \\
\hline & CFML $90-59$ & 91 & & \\
\hline & CFML 90-63 & 87 & 1.2 & \\
\hline & CFML 90-55 & 86 & 0.5 & \\
\hline & CFML $90-57$ & 86 & 1.0 & \\
\hline \multirow[t]{2}{*}{ Subcluster IIc } & CFML $90-53$ & 41 & 8.0 & \\
\hline & CFML $90-100$ & 29 & & \\
\hline \multirow[t]{4}{*}{ Subcluster IIa } & CFML $90-139$ & 49 & 7.4 & \\
\hline & CFML 90-36 & 48 & 7.5 & \\
\hline & CFML $90-33$ & 42 & 9.2 & \\
\hline & CFML 90-34 & 40 & 9 & \\
\hline \multirow[t]{3}{*}{ Subcluster IIb } & CFML 90-46 & 54 & 6.7 & \\
\hline & CFML 90-49 & 50 & 8.4 & \\
\hline & CFML $90-52$ & 50 & 7.6 & \\
\hline \multirow[t]{3}{*}{ P. putida biovar A } & DSMZ 50208 & 48 & 7.9 & \\
\hline & CFML $90-48$ & 45 & 8.8 & \\
\hline & CFML $90-39$ & 41 & 9.8 & \\
\hline \multirow[t]{11}{*}{ P. putida biovar A } & ATCC $12633^{\mathrm{T}}$ & 40 & 9.2 & \\
\hline & CFML 90-42 & 40 & 7.6 & \\
\hline & CFML 90-47 & 37 & 10.5 & \\
\hline & CFML 90-51 & 36 & 7.9 & \\
\hline & CFML 90-40 & 35 & & \\
\hline & CFML $90-50$ & 35 & & \\
\hline & CFML $90-43$ & 30 & & \\
\hline & CFML 90-38 & 29 & & \\
\hline & CFML $90-37$ & 24 & & \\
\hline & CFML $90-44$ & 20 & & \\
\hline & CFML $90-45$ & 21 & & \\
\hline \multirow[t]{4}{*}{ Subcluster IId } & CFML 90-135 & 44 & 9.2 & \\
\hline & CFML $90-136$ & 42 & 7.1 & \\
\hline & CFML 90-138 & 40 & 8.9 & \\
\hline & CFML $90-35$ & 11 & & \\
\hline P. putida biovar B & ATCC 17484 & 15 & & \\
\hline P. putida biovar B & ATCC 17430 & 17 & & \\
\hline P. putida biovar B & CCUG 1317 & 8 & & \\
\hline P. aeruginosa & $\operatorname{ATCC} 10145^{\mathrm{T}}$ & 6 & & \\
\hline$P$. aeruginosa & ATCC 27853 & 11 & & \\
\hline$P$. aeruginosa & ATCC 15692 & 11 & & \\
\hline P. fluorescens biovar I & ATCC $13525^{\mathrm{T}}$ & 16 & & \\
\hline P. fluorescens biovar I & ATCC 17563 & 10 & & \\
\hline P. fluorescens biovar I & ATCC 17397 & 26 & & \\
\hline$P$. fluorescens biovar II & ATCC 17816 & 15 & & \\
\hline P. fluorescens biovar II & DSMZ 50106 & 17 & & \\
\hline P. fluorescens biovar II & ATCC 17815 & 20 & & \\
\hline P. fluorescens biovar II & ATCC 17482 & 16 & & \\
\hline P. fluorescens biovar III & ATCC 17559 & 13 & & \\
\hline P. fluorescens biovar III & ATCC 17400 & 18 & & \\
\hline P. fluorescens biovar IV & DSMZ 50415 & 19 & & \\
\hline P. fluorescens biovar IV & ATCC 12983 & 15 & & \\
\hline P. fluorescens biovar V & ATCC 14150 & 16 & & \\
\hline$P$. fluorescens biovar V & ATCC 17518 & 17 & & \\
\hline P. fluorescens biovar $\mathrm{V}$ & ATCC 15916 & 18 & & \\
\hline P. fluorescens biovar $\mathrm{V}$ & ATCC 17386 & 33 & 14.3 & \\
\hline$P$. fluorescens biovar $\mathrm{V}$ & DSMZ 50148 & 18 & & \\
\hline P. fluorescens biovar $\mathrm{V}$ & ATCC 17573 & 16 & & \\
\hline
\end{tabular}

TABLE 1-Continued

\begin{tabular}{|c|c|c|c|c|}
\hline \multirow{2}{*}{$\begin{array}{c}\text { Taxon (as received) } \\
\text { or phenotypic } \\
\text { subcluster }\end{array}$} & \multirow{2}{*}{ Strain $^{a}$} & \multicolumn{2}{|c|}{$\begin{array}{l}\text { Labeled DNA from } \\
\text { strain CFML } 90-60^{\mathrm{T}}\end{array}$} & \multirow{2}{*}{$\begin{array}{c}\mathrm{G}+\mathrm{C} \\
\text { content } \\
(\mathrm{mol} \%)\end{array}$} \\
\hline & & $\begin{array}{l}\text { Relative binding } \\
\text { ratio }(\%)\end{array}$ & $\begin{array}{l}\Delta T_{m} \\
\left({ }^{\circ} \mathrm{C}\right)\end{array}$ & \\
\hline P. marginalis & ATCC $10844^{\mathrm{T}}$ & 17 & & \\
\hline P. marginalis & DSMZ 50275 & 20 & & \\
\hline P. marginalis & DSMZ 50276 & 18 & & \\
\hline P. chlororaphis & DSMZ $50083^{T}$ & 23 & & \\
\hline P. chlororaphis & ATCC 9447 & 25 & & \\
\hline P. chlororaphis & ATCC 17414 & 18 & & \\
\hline P. aureofaciens & CCEB $518^{\mathrm{T}}$ & 11 & & \\
\hline P. aureofaciens & ATCC 17415 & 17 & & \\
\hline P. lundensis & $\mathrm{CCM} 573^{\mathrm{r}}$ & 7 & & \\
\hline P. lundensis & CCUG 18758 & 10 & & \\
\hline P. syringae & ATCC $19310^{T}$ & 11 & & \\
\hline P. savastanoi & CFBP $1670^{\mathrm{T}}$ & 11 & & \\
\hline P. savastanoi & CFBP 2088 & 12 & & \\
\hline P. savastanoi & CFBP 1838 & 12 & & \\
\hline$P$. viridiflava & ATCC $13223^{\mathrm{T}}$ & 11 & & \\
\hline P. cichorii & DSMZ $50259^{\mathrm{T}}$ & 14 & & \\
\hline$P$. agarici & ATCC $25941^{\mathrm{T}}$ & 13 & & \\
\hline$P$. asplenii & ATCC $23835^{\mathrm{T}}$ & 13 & & \\
\hline P. caricapapayae & NCPPB $1873^{T}$ & 6 & & \\
\hline P. tolaasii & NCPPB $2192^{T}$ & 22 & & \\
\hline P. tolaasii & NCPPB 1616 & 18 & & \\
\hline P. stutzeri & ATCC $17588^{\mathrm{T}}$ & 9 & & \\
\hline P. stutzeri & ATCC 17591 & 8 & & \\
\hline P. stutzeri & ATCC 17587 & 8 & & \\
\hline P. stutzeri & ATCC 17686 & 6 & & \\
\hline$P$. mendocina & ATCC $25411^{\mathrm{T}}$ & 9 & & \\
\hline P. mendocina & ATCC 25412 & 11 & & \\
\hline$P$. alcaligenes & ATCC $14909^{\mathrm{T}}$ & 14 & & \\
\hline P. pseudoalcaligenes & ATCC $17440^{\mathrm{T}}$ & 6 & & \\
\hline$P$. pseudoalcaligenes & ATCC 12815 & 10 & & \\
\hline P. fragi & ATCC $4973^{T}$ & 13 & & \\
\hline P. fragi & ATCC 27362 & 15 & & \\
\hline
\end{tabular}

${ }^{a}$ Abbreviations: CFML, Collection de la Faculté de Médecine de Lille, Lille, France; ATCC, American Type Culture Collection, Rockville, Md.; CCEB, Culture Collection of Entomogenous Bacteria, Institute of Entomology, Czechoslovakia Academy of Sciences, Prague, Czech Republic: CCM, Czechoslovak Collection of Microorganisms, J.E. Purkyne University, Brno, Czech Republic; CCUG, Culture Collection, University of Göteborg, Göteborg, Sweden; DSMZ, Deutsche Sammlung von Mikroorganismen und Zellkulturen GmbH, Braunschweig, Germany; NCIB, National Collection of Industrial Bacteria, Aberdeen, Scotland, United Kingdom; NCPPB, National Collection of Plant Pathogenic Bacteria, Plant Pathology Laboratory, Hatching Green, Harpenden, England, United Kingdom; PDDCC, Culture Collection of Plant Diseases Division, New Zealand Department of Scientific and Industrial Research, Auckland, New Zealand.

1989). A total of 57 type and collection strains were also included in this study for control purposes (Table 1). All of the bacteria were cultured routinely on Mueller-Hinton medium plates which were incubated at $30^{\circ} \mathrm{C}$

Conventional, assimilation, and enzymatic tests. Conventional, assimilation, and enzymatic tests were performed previously (14).

DNA hybridization experiments and thermal stability of duplexes. DNA extraction was performed as described previously $(1,28)$. The purity and quality of each DNA preparation were checked by determining the $A_{260} / A_{280}$ and $A_{260} / A_{230}$ ratios as described by Marmur and Doty (29). Native DNA was labeled in vitro with $\left[{ }^{3} \mathrm{H}\right]$ cytosine by nick translation $(20)$. The procedure used for the hybridization experiments (the $\mathrm{S} 1$ nuclease-trichloroacetic acid method) has been described previously $(7,20)$. The thermal stability of duplexes was determined by using the method of Crosa et al. (7). The divergence between DNAs was estimated by determining the $\Delta T_{m}$ value. 
TABLE 2. Sources of $P$. monteilii strains

\begin{tabular}{|c|c|c|}
\hline Strain $^{a}$ & Source & Sender \\
\hline CFML 90-54 & Placenta & $\begin{array}{l}\text { Hansen Bruxelle University } \\
\text { Hospital }\end{array}$ \\
\hline CFML 90-55 & Stool & Lille University Hospital \\
\hline CFML 90-56 & Bile & Lille University Hospital \\
\hline CFML 90-57 & Biological fluid & Freney Lyon University Hospital \\
\hline CFML 90-58 & Clinical isolate & Freney Lyon University Hospital \\
\hline CFML 90-59 & Clinical isolate & Lille University Hospital \\
\hline CFML $90-60^{\mathrm{T}}$ & Bronchial aspirate & Freney Lyon University Hospital \\
\hline CFML 90-61 & Bronchial aspirate & Lille University Hospital \\
\hline CFML 90-62 & Urine & $\begin{array}{l}\text { Monteil Strasbourg University } \\
\text { Hospital }\end{array}$ \\
\hline CFML 90-63 & Pleural fluid & Lille University Hospital \\
\hline
\end{tabular}

${ }^{a}$ CFML, Collection de la Faculté de Médecine de Lille, Lille, France.

$\mathbf{G}+\mathbf{C}$ content determination. The $\mathrm{G}+\mathrm{C}$ content was calculated from the thermal denaturation curve by using the equation of De Ley (8).

PCR amplification. PCR amplification was performed with a model 480 DNA thermal cycler (Perkin-Elmer Corp.) by using a PCR mixture (final volume, 100 $\mu l)$ containing each of the deoxynucleoside triphosphates at a concentration of $200 \mu \mathrm{M}$, each of the primers (PS1 and PS2) (10) at a concentration of $1 \mathrm{mM}, 1$ $\mu \mathrm{g}$ of target DNA, and $2.5 \mathrm{U}$ of Taq DNA polymerase. A total of 30 cycles of amplification were performed; each cycle consisted of template DNA denaturation at $94^{\circ} \mathrm{C}$ for $1 \mathrm{~min}$, primer annealing at $60^{\circ} \mathrm{C}$ for $1 \mathrm{~min}$, and primer extension at $72^{\circ} \mathrm{C}$ for $2 \mathrm{~min}$. Before the DNA polymerase was added, each sample was denatured at $94^{\circ} \mathrm{C}$ for $5 \mathrm{~min}$. A $10-\mu$ l portion of the amplified fragment preparation was loaded onto a $1 \%$ (wt/vol) agarose gel for electrophoresis.

The specificity of the amplified DNA was confirmed by Southern blot hybridization with an OprI DNA probe. This probe was obtained from the PCR products after amplification of the DNA of the $O p r I$ gene-positive reference strain $(10,44)$. The amplified fragment was desalted by low-melting-point agarose gel electrophoresis and purification by using a GeneClean kit (Amersham) and was labeled with horseradish peroxidase by using the ECL labeling system (Amersham). The methods used for Southern transfer and hybridization have been described previously (45); 100-bp DNA (Gibco BRL) was used as a molecular weight marker.

\section{RESULTS}

Conventional, assimilation, and enzymatic tests. The phenotypic results obtained for all subcluster IIc strains have been published previously (14). The results obtained for the 10 strains included in Table 2 are shown in Table 3 and were compared to the results obtained for pathogenic or saprophytic members of section I of Palleroni (32).

DNA relatedness. The results of DNA relatedness experiments obtained with labeled DNA of subcluster IIc strain CFML $90-60^{\mathrm{T}}$ are presented in Table 1 . The levels of hybridization between strain CFML $90-60^{\mathrm{T}}$ and the 11 other isolates belonging to the same subcluster ranged from 29 to $100 \%$. Ten strains of this subcluster were 86 to $100 \%$ related (Table 1). For the three lowest relatedness values $(86,86$, and $87 \%)$, the $\Delta T_{m}$ values were $1,0.5$, and $1.2^{\circ} \mathrm{C}$, respectively. The two other strains of this phenotypic subcluster, strains CFML 90-53 and CFML 90-100, had relative binding ratios of only 29 and $41 \%$, respectively, with labeled DNA from strain CFML $90-60^{\mathrm{T}}$. Hybridization experiments were also performed with all of the strains of the three other phenotypic subclusters described previously (subclusters IIa, IIb and IId) (14). Phenotypic subcluster IIb contained 15 clinical isolates and two culture collection strains of $P$. putida biovar A (ATCC $12633^{\mathrm{T}}$ and DSMZ 50208). Phenotypic subclusters IIa and IId each included four wild strains, all of which were isolated from clinical specimens. The levels of DNA relatedness between strain CFML $90-60^{\mathrm{T}}$ and the strains of the other subclusters varied between 21 and $54 \%$ for subcluster IIb strains, between 40 and $49 \%$ for subcluster IIa strains, and between 11 and $44 \%$ for subcluster IId strains (Table 1 ). The $\Delta T_{m}$ values were 6.7 to $10.5^{\circ} \mathrm{C}$. The lev- els of reassociation between the reference strain of subcluster IIc and cultures belonging to the different species of Pseudomonas section I of Palleroni (32), the possibly related species Pseudomonas lundensis, $P$. fragi, and Pseudomonas savastanoi, and fluorescent members of Pseudomonas section V of Palleroni (32) are also shown in Table 1. For all of these taxa (except $P$. putida biovar A) the levels of relatedness were in the range of 6 to $33 \%$.

DNA base composition. The $\mathrm{G}+\mathrm{C}$ contents of strains CFML 90-60 ${ }^{\mathrm{T}}$, CFML 90-56, CFML 90-54, and CFML 90-61 were 60, $61,60.5$, and $60 \mathrm{~mol} \%$, respectively (Table 1), as determined by the thermal denaturation procedure.

PCR amplification. A fragment of the expected size (249 bp) was amplified by PCR for all 10 strains (Table 2) of subcluster IIc. Identical results were obtained after Southern blot hybridization with the $O p r I$ DNA probe from the reference strain (10, 44).

\section{DISCUSSION}

A total of 37 of the 39 strains isolated from clinical specimens and phenotypically identified as fluorescent pseudomonads were members of one phenotypic cluster, cluster II, which could be subdivided into four subclusters, subclusters IIa to IId (14). Phenotypically, subcluster IIc is most similar to subcluster IIb, which contains the type and collection strains of P. putida biovar A.

In order to further determine the taxonomic position of subcluster IIc within Pseudomonas sensu stricto (12), we performed DNA-DNA hybridization experiments with members of this subcluster (12 strains) and with the type strains and other representative strains of other species of this genus (Ta-

TABLE 3. Characteristics of 10 P. monteilii strains

\begin{tabular}{|c|c|c|}
\hline Characteristic & $\begin{array}{l}\text { Reaction of } \\
\text { most strains }\end{array}$ & $\begin{array}{l}\text { Reaction of } \\
\text { type strain }\end{array}$ \\
\hline \multicolumn{3}{|l|}{ Conventional tests } \\
\hline Tyrosine & $+(4)^{a}$ & + \\
\hline Urea & $\mathrm{b}$ & + \\
\hline Cetrimide & $+(1)$ & + \\
\hline 2,3,5-Triphenyltetrazolium chloride & $+(2)$ & + \\
\hline Growth on phenylpyruvic acid or at $4^{\circ} \mathrm{C}$ & $-(1)$ & - \\
\hline \multicolumn{3}{|l|}{ Utilization of: } \\
\hline Glycine, L-tyrosine & $-(1)$ & - \\
\hline L-Histidine, creatine, L-phenylalanine & $+(1)$ & + \\
\hline L-Citrulline & $-(3)$ & - \\
\hline DL-Norvaline & $+(4)$ & + \\
\hline L-Serine, histamine & $+(2)$ & + \\
\hline L-Threonine & $-(4)$ & - \\
\hline Trigonelline & $+(3)$ & - \\
\hline Malonate & $+(4)$ & - \\
\hline D-Malate & $\mathrm{b}$ & - \\
\hline \multicolumn{3}{|l|}{ Enzymatic tests } \\
\hline $\begin{array}{l}\text { L-Proline arylamidase, methionine } \\
\text { arylamidase }\end{array}$ & $+(3)$ & + \\
\hline L-Pyrrolidone arylamidase & $-(1)$ & + \\
\hline $\begin{array}{l}\text { L-Arginine arylamidase, L-lysyl-L-alanine aryl- } \\
\text { amidase, L-seryl-L-tyrosine arylamidase }\end{array}$ & $-(1)$ & - \\
\hline $\begin{array}{l}\text { L-Glycyl-L-tryptophan arylamidase, } \\
\text { esterase } C_{12}\end{array}$ & $+(2)$ & + \\
\hline L-Seryl-L-methionine arylamidase & b & - \\
\hline
\end{tabular}

+ , positive; - , negative; b, $50 \%$ of the strains are positive. The numbers in parentheses are the numbers of strains that deviate from the most common result. 
ble 1). The results obtained show that 10 subcluster IIc strains form a homogeneous group with levels of hybridization of 86 to $100 \%$ (Table 1). The $\Delta T_{m}$ values were less than $1.2^{\circ} \mathrm{C}$, indicating that these organisms are sufficiently closely related to warrant recognition as members of a single species since at present the definition of a genomic species (49) states that the strains of a species, should have DNA hybridization values of $70 \%$ or more and $\Delta T_{m}$ values of $5^{\circ} \mathrm{C}$ or less (both values must be considered) and that the results of other techniques should decide if a genospecies deserves species status. The two other phenotypic subcluster IIc strains, CFML 90-53 and CFML $90-100$, were expelled from the group despite the fact that they are phenotypically indistinguishable from the 10 other strains of this subcluster. These two strains may represent one or two additional genospecies for which supplementary studies will be needed to determine their taxonomic status and their relationships to the genus Pseudomonas.

The levels of hybridization between strain CFML $90-60^{\mathrm{T}}$ and members of other species belonging to the genus Pseudomonas were low. The highest hybridization values were obtained with biovar A strains of $P$. putida (level of hybridization with collection strain DSMZ 50208, 48\%), emphasizing that our group of 10 strains belongs to the genus Pseudomonas sensu stricto (13). These 10 strains share 20 characteristics with $P$. aeruginosa, $P$. fluorescens (all biovars), $P$. chlororaphis, and $P$. putida (biovars A and B), and, like these species, they were unable to use 10 other substrates as sole carbon and energy sources. In addition, the PCR for the gene for OprI lipoprotein (10), which could be amplified only in members of the authentic genus Pseudomonas, was positive when the 10 strains of subcluster IIc were tested.

The average DNA G+C content was $60.5 \pm 0.5 \mathrm{~mol} \%$ for the four strains studied. This value is typical of the genus Pseudomonas sensu stricto. Determination of the $\mathrm{G}+\mathrm{C}$ content is one of the classical genotypic methods and is considered part of the standard description of a bacterial taxon. Generally, the range observed is not more than $3 \%$ within a well-defined species and not more that $10 \%$ within a well-defined genus $(9$, $50,55)$.

On the basis of the results described above (DNA-DNA hybridization, $\Delta T_{m}$, and $\mathrm{G}+\mathrm{C}$ content data), it appeared that the 10 strains of subcluster IIc (Table 2) represented a new Pseudomonas species, for which we propose the name Pseudomonas monteilii. The sources of these strains are given in Table 2.

Description of Pseudomonas monteilii sp. nov. Pseudomonas monteilii (mon.tei'li.i M. L. masc. gen. n. monteilii, of Monteil, in honor of Henri Monteil, a French microbiologist, for his contribution to medical microbiology).

Biochemical and physiological characteristics. The $10 P$. monteilii strains are gram negative, motile, asporogenous, and rod shaped. Colonies on nutrient agar are circular and nonpigmented. They are nonhemolytic on blood agar. The cells are lipase, elastase, lecithinase, and tetrathionate reductase negative. Arginine dihyrolase, catalase, and cytochrome oxidase are produced. The temperature range for growth is 10 to $36^{\circ} \mathrm{C}$, and optimal growth occurs at $30^{\circ} \mathrm{C}$. Growth occurs in the presence of $3 \% \mathrm{NaCl}$ but not in the presence of 5 or $7 \% \mathrm{NaCl}$. No strain reduces nitrate to nitrite or to gas; the strains are not able to form levan from sucrose but they are able to use citrate and arginine. Tributyrin and fibrinolysis tests are negative.

Poly- $\beta$-hydroxybutyrate is not accumulated as a carbon reserve material. Phenazine pigments are not produced on King A medium (25). Strains are unable to grow at $41^{\circ} \mathrm{C}$. Indole, coagulase, and $\beta$-xylosidase are not produced. Gelatin is not liquefied. Esculin and starch are not hydrolyzed. Phenylalanine is not deaminated, and lysine and ornithine are not decarboxy- lated. The Voges-Proskauer reaction and the $o$-nitrophenyl- $\beta$ -galactopyranoside test are negative. There is no action against DNA or RNA. The strains are chondroitin negative.

Assimilation of carbon compounds. All strains utilize the following substrates as carbon and energy sources: glycerol, D-ribose, inositol, D-glucose, D-fructose, L-glutamate, L-arabinose, 2-ketogluconate, DL-glycerate, DL-3-hydroxybutyrate, gluconate, isobutyrate, L-proline, D-alanine, L-alanine, L-leucine, L-isoleucine, L-norleucine, L-valine, L-aspartate, L-ornithine, L-lysine, L-arginine, betaine, $\beta$-alanine, sarcosine, DL-4-aminobutyrate, DL-5-aminovalerate, butylamine, amylamine, ethanolamine, benzylamine, diaminobutane, spermine, aconitate, phenylacetate, succinate, fumarate, L-malate, acetate, propionate, butyrate, $n$-valerate, isovalerate, $n$-caproate, heptanoate, caprylate, caprate, glutarate, DL-lactate, puryvate, citrate, benzoate, and $p$-hydroxybenzoate.

No strain uses the following substrates as sole carbon and energy sources: L-xylose, $\alpha$-methyl-D-mannoside, salicin, lactose, D-melibiose, inulin, D-tagatose, D-fucose, erythritol, Darabinose, D-xylose, adonitol, $\beta$-methylxyloside, D-galactose, Dmannose, L-sorbose, L-rhamnose, dulcitol, sorbitol, $\alpha$-methylD-glucoside, $N$-acetylglucosamine, amygdalin, arbutin, esculin, D-cellobiose, maltose, sucrose, trehalose, D-melezitose, D-raffinose, starch, glucogen, xylitol, $\beta$-gentobiose, D-turanose, D-lyxose, L-fucose, D-arabitol, 5-ketogluconate, L-cysteine, Dtryptophan, DL-2-aminobutyrate, L-methionine, L-tryptophan, DL-kynurenine, DL-3-aminobutyrate, DL-2-aminobenzoate, DL3-aminobenzoate, DL-4-aminobenzoate, ethylamine, acetamide, tryptamine, glucosamine, levulinate, iso-phthalate, oxalate, maleate, adipate, pimelate, suberate, azelate, sebacate, D-tartrate, L-tartrate, meso-tartrate, citrate, mesaconate, $o$-hydroxybenzoate, $m$-hydroxybenzoate, D-mandelate, L-mandelate, phthalate, terephthalate, glycerate, oxalate, L-arabitol, mannitol, glycolate, citraconate, itaconate, and mucate.

Enzymatic tests. All strains possess the following enzyme activities: L-phenylalanine arylamidase, L-lysine arylamidase, L-alanine arylamidase, $\gamma$-glutamyl-transferase, glycyl-phenylalanine arylamidase, L-tryptophan arylamidase, glycyl-L-alanine arylamidase, esterase $C_{4}$, esterase $C_{6}$, esterase $C_{8}$, esterase $C_{9}$, esterase $\mathrm{C}_{10}$, and esterase $\mathrm{C}_{18}$.

No strains possess the following enzyme activities: L-histidylL-phenylalanine arylamidase, glycyl-glycine arylamidase, L-hydroxyproline arylamidase, L-histidine arylamidase, glycine arylamidase, L-aspartate arylamidase, glycyl-proline arylamidase, leucyl-glycine arylamidase, L-glutamine arylamidase, $\alpha$-L-glutamate arylamidase, L-isoleucine arylamidase, L-ornithine arylamidase, L-serine arylamidase, L-threonine arylamidase, $N$ carboxybenzoyl-glycyl-glycyl-arginine arylamidase, $\beta$-alanine arylamidase, L-alanyl-L-arginine arylamidase, L-alanyl-Lphenylalanyl-L-proline arylamidase, L-alanyl-L-phenylalanyl-Lprolyl-L-alanine arylamidase, L-arginyl-L-arginine arylamidase, $\alpha$-L-aspartyl-L-alanine arylamidase, $\alpha-\mathrm{L}$-aspartyl-Larginine arylamidase, $\alpha-\mathrm{L}-\mathrm{glutamyl}-\mathrm{L}$-histidine arylamidase, glycyl-L-arginine arylamidase, L-histidyl-L-leucyl-L-histidine arylamidase, L-histidyl-L-serine arylamidase, L-lysyl-L-lysine arylamidase, L-phenylalanyl-L-arginine arylamidase, Lphenylalanyl-L-proline arylamidase, L-phenylalanyl-L-prolylL-alanine arylamidase, L-seryl-L-methionine arylamidase, L-valyl-L-tyrosyl-L-serine arylamidase, L-lysyl-L-serine-4-methoxyarylamidase, $\alpha$-D-glucosidase, $\beta$-D-glucosidase, $\alpha$-maltosidase, $N$-carboxybenzoyl-arginine-4-methoxy arylamidase, $N$-benzoylleucine arylamidase, $S$-benzoyl-cysteine arylamidase, $\alpha$-L-glutamyl- $\alpha$-L-glutamic arylamidase, L-leucyl-L-leucyl-L-valyl-L-tyrosyl-L-serine arylamidase, $N$-benzoyl-L-alanine-4-methoxy arylamidase, $N$-acetyl-glycyl-L-lysine arylamidase, $\alpha$-D-galactosidase, $\beta$-D-galactosidase, phospho- $\beta$-D-galactosidase, $\alpha$-L-ar- 
TABLE 4. Differentiation of $P$. monteilii from nonphytopathogenic fluorescent members of section I of the genus Pseudomonas

\begin{tabular}{|c|c|c|c|c|c|c|c|c|c|c|c|}
\hline Characteristic & $\begin{array}{l}\text { P. mon- } \\
\text { teiliii }\end{array}$ & $\begin{array}{l}\text { P. aerugi- } \\
\text { nosa }\end{array}$ & $\begin{array}{l}\text { P. fluorescens } \\
\text { biovar I }\end{array}$ & $\begin{array}{l}\text { P. fluorescens } \\
\text { biovar II }\end{array}$ & $\begin{array}{l}\text { P. fluorescens } \\
\text { biovar III }\end{array}$ & $\begin{array}{l}\text { P. fluorescens } \\
\text { biovar IV }\end{array}$ & $\begin{array}{l}\text { P. fluorescens } \\
\text { biovar V }\end{array}$ & $\begin{array}{l}\text { P. chloro- } \\
\text { raphis }\end{array}$ & $\begin{array}{l}\text { P. aureo- } \\
\text { faciens }\end{array}$ & $\begin{array}{l}\text { P. putida } \\
\text { biovar A }\end{array}$ & $\begin{array}{l}\text { P. putida } \\
\text { biovar B }\end{array}$ \\
\hline Pyocyanin production & $--^{a}$ & + & -. & -- & - & - & - & - & - & - & - \\
\hline Lipase & - & + & d & - & d & d & d & $\mathrm{d}$ & d & d & d \\
\hline Denitrification & - & + & - & + & + & + & - & + & + & - & - \\
\hline Growth at $4^{\circ} \mathrm{C}$ & - & - & + & + & + & + & d & + & + & d & + \\
\hline Growth at $41^{\circ} \mathrm{C}$ & - & + & - & - & - & - & - & - & - & - & - \\
\hline Lecithinase & - & - & + & $\mathrm{d}$ & + & + & d & + & d & - & - \\
\hline Gelatin liquefaction & - & + & + & + & + & + & + & + & + & - & -- \\
\hline \multicolumn{12}{|l|}{ Assimilation of: } \\
\hline D-Ribose & + & + & + & + & d & + & d & + & + & $\mathrm{d}$ & $\mathrm{d}$ \\
\hline D-Xylose & - & - & + & d & d & d & d & - & - & $\mathrm{d}$ & $\mathrm{d}$ \\
\hline L-Arabinose & + & - & + & + & d & + & d & - & + & $\mathrm{d}$ & + \\
\hline L-Rhamnose & - & - & - & d & $\mathrm{d}$ & - & d & - & - & - & - \\
\hline Glucose & + & + & + & + & + & + & + & + & d & + & + \\
\hline D-Mannose & - & - & + & + & + & + & d & + & + & d & $\mathrm{d}$ \\
\hline Mannitol & - & + & + & + & $\mathrm{d}$ & + & d & + & + & $\mathrm{d}$ & d \\
\hline D-Galactose & - & - & + & + & d & + & d & d & + & - & $\mathrm{d}$ \\
\hline D-Fructose & + & + & + & d & + & + & + & d & $\mathrm{d}$ & + & + \\
\hline Sucrose & - & - & + & + & - & + & d & + & d & - & $\mathrm{d}$ \\
\hline Trehalose & - & - & + & + & d & + & d & + & d & - & - \\
\hline Gluconate & + & + & + & + & + & + & + & + & $\mathrm{d}$ & + & + \\
\hline 2-Ketogluconate & + & + & + & + & + & $\mathrm{d}$ & + & + & d & d & + \\
\hline Mucate & - & - & + & + & d & + & + & + & + & d & + \\
\hline Propionate & + & + & + & + & d & + & + & + & + & + & + \\
\hline Butyrate & + & + & - & d & d & + & d & + & $\mathrm{d}$ & + & + \\
\hline Isobutyrate & + & + & - & d & d & - & d & - & d & d & d \\
\hline Valerate & + & + & $\mathrm{d}$ & d & d & - & $\mathrm{d}$ & + & + & + & + \\
\hline Isovalerate & + & + & d & d & d & - & d & + & + & + & + \\
\hline Caproate & + & + & + & d & + & + & + & $\mathrm{d}$ & + & + & + \\
\hline Malonate & d & + & + & + & d & + & d & + & + & d & + \\
\hline Adipate & - & + & - & - & d & - & - & - & -- & - & d \\
\hline Sebacate & - & + & - & - & d & - & - & - & - & - & d \\
\hline Pimelate, suberate & - & d & - & - & d & - & - & - & - & - & - \\
\hline Azelate & - & + & - & - & d & - & - & - & - & - & - \\
\hline D-Malate & d & d & - & d & $\mathrm{d}$ & + & d & $\mathrm{d}$ & - & d & d \\
\hline D-Tartrate & - & - & - & d & - & - & d & - & - & d & d \\
\hline L-Tartrate & - & - & - & - & - & + & - & $\mathrm{d}$ & - & d & d \\
\hline$m$-Tartrate & - & - & - & - & d & - & d & - & - & d & - \\
\hline Glycolate & - & - & - & - & - & - & - & - & - & d & - \\
\hline Glycerate & + & + & + & + & d & + & d & + & + & d & + \\
\hline Aconitate & + & + & + & + & d & + & d & $\mathrm{d}$ & + & + & + \\
\hline Erythritol & - & - & d & d & + & - & d & - & - & - & - \\
\hline Sorbitol & - & - & + & + & d & + & d & - & - & - & d \\
\hline Inositol & + & - & d & + & d & + & d & + & + & - & - \\
\hline Adonitol & - & - & + & - & d & - & d & - & - & - & - \\
\hline D-Mandelate & - & - & - & - & - & - & - & - & - & d & d \\
\hline L-Mandelate & - & + & - & - & - & - & d & - & - & - & d \\
\hline Benzoate & + & + & d & d & d & + & d & + & $\mathrm{d}$ & d & + \\
\hline$o$-Hydroxybenzoate & - & - & - & - & - & - & - & d & - & d & $\mathrm{d}$ \\
\hline$m$-Hydroxybenzoate & - & - & - & - & - & - & - & $\mathrm{d}$ & d & d & $\mathrm{d}$ \\
\hline$p$-Hydroxybenzoate & + & + & + & + & d & + & d & + & + & + & + \\
\hline Phenylacetate & + & - & - & - & d & - & d & d & + & d & + \\
\hline$\alpha$-Aminobutyrate & + & - & - & - & - & - & - & - & - & - & d \\
\hline D-Tryptophan & - & - & - & - & - & - & - & - & - & - & d \\
\hline Creatine & + & - & - & - & d & - & - & - & - & $\mathrm{d}$ & $\mathrm{d}$ \\
\hline Glycine & - & $\mathrm{d}$ & - & - & d & - & d & - & - & d & + \\
\hline D-Alanine & + & + & + & + & + & + & - & + & - & + & + \\
\hline L-Serine & d & d & + & d & + & + & $\mathrm{d}$ & d & + & d & d \\
\hline L-Leucine & + & + & + & d & + & + & + & + & + & + & + \\
\hline L-Isoleucine, L-valine & + & d & + & + & + & + & + & + & + & + & + \\
\hline L-Lysine & + & + & + & d & d & + & d & d & $\mathrm{d}$ & + & d \\
\hline L-Ornithine & + & + & + & d & d & d & d & d & + & + & + \\
\hline L-Citrulline & d & d & d & d & d & - & d & d & $\mathrm{d}$ & d & d \\
\hline L-Histidine & + & + & + & d & + & + & d & + & + & + & + \\
\hline L-Phenylalanine & + & d & d & d & d & + & d & d & + & + & + \\
\hline L-Tryptophan & - & d & + & d & d & - & d & + & + & - & + \\
\hline L-Kynurenine & - & + & d & d & d & - & $\mathrm{d}$ & + & + & - & + \\
\hline Ethanolamine & + & d & + & d & d & + & d & d & + & d & d \\
\hline Benzylamine & + & - & - & - & d & - & d & - & - & d & + \\
\hline Histamine & d & + & $\mathrm{d}$ & - & d & - & d & d & d & d & + \\
\hline Tryptamine & - & - & - & $\mathrm{d}$ & d & - & - & - & - & d & + \\
\hline Butylamine & + & - & - & - & - & - & d & - & $\mathrm{d}$ & + & + \\
\hline Amylamine & + & - & - & d & $\mathrm{d}$ & - & d & - & + & d & + \\
\hline Sarcosine & + & d & + & d & d & + & d & d & + & + & + \\
\hline Acetamide & - & + & - & - & - & - & - & - & - & d & d \\
\hline Trigonelline & d & - & d & d & d & - & d & - & - & d & + \\
\hline
\end{tabular}

${ }^{a}-, 90 \%$ or more of the strains are negative;,$+ 90 \%$ or more of the strains are positive; $\mathrm{d}, 11$ to $89 \%$ of the strains are positive. 
abinosidase, $\beta$-D-galacturonohydrolase, $\beta$-D-glucuronidase, $\beta$-maltosidase, $N$-acetyl- $\alpha$-D-glucosaminidase, $\beta$-D-fucosidase, $\beta$-L-fucosidase, $\beta$-D-lactosidase, $\alpha$-D-mannosidase, $\beta$-D-mannosidase, $\alpha$-D-xylosidase, $\quad \beta$-D-xylosidase, $\quad N$-acetyl- $\beta$-D-glucosaminidase, $\beta$-L-fucosidase, and esterase $C_{16}$.

Variable characteristics of $10 P$. monteilii strains are shown in Table 3. All of the reactions of the type strain are the same as the reactions of the majority of the strains of $P$. monteilii except the reactions in the following three tests: assimilation of trigonelline and malonate and presence of L-pyrrolidone arylamidase. The $P$. monteilii strains are phenotypically and genotypically homogeneous and can be differentiated from related nonphytopathogenic fluorescent members of section I of the genus Pseudomonas (32) by several phenotypic features (Table 4). Differentiation of $P$. monteilii and $P$. aeruginosa is based on pyocyanin production, lipase activity, denitrification, growth at $41^{\circ} \mathrm{C}$, and assimilation of L-arabinose, mannitol, adipate, sebecate, azelate, inositol, L-mandelate, phenylacetate, $\alpha$-aminobutyrate, L-kynurenine, benzylamine, butylamine, amylamine, and acetamide. $P$. monteilii and $P$. fluorescens clearly differ phenotypically since all strains of $P$. fluorescens liquefy gelatin and are able to grow at $4^{\circ} \mathrm{C}$, whereas strains of $P$. monteilii are unable to grow at this temperature and are unable to liquefy gelatin. Moreover, most strains of $P$. fluorescens utilize D-mannose, mannitol, D-galactose, and mucate, whereas all strains of $P$. monteilii are unable to utilize these compounds. Conversely, all strains of $P$. monteilii are able to grow on $\alpha$-aminobutyrate, creatine (except one strain), and butylamine, whereas most strains of $P$. fluorescens fail to do so. Phenotypically, $P$. monteilii is most similar to $P$. putida, but these two species can be differentiated by assimilation of inositol, L-tartrate, D-tartrate, $o$-hydroxybenzoate, $m$-hydroxybenzoate, tryptamine, D-mandelate, acetamide, D-xylose, mannitol, and mucate and by the presence of glycyl-glycine arylamidase, L-glutamine arylamidase, and L-arginine arylamidase (Table 4) (14).

Strains of $P$. monteilii were isolated from clinical specimens (Table 2). Type strain CFML $90-60$ has been deposited in the Collection Institut Pasteur) as CIP 104883; it was isolated in Lyon, France, from a bronchial aspirate, and its $\mathrm{G}+\mathrm{C}$ content is $60 \mathrm{~mol} \%$.

Clinical significance. The clinical significance of $P$. monteilii is not known. Future isolates of this new organism should be investigated to determine their role in nosocomial infections. At present, our hypothesis is that $P$. monteilii is a rare opportunistic pathogen or colonizer.

\section{ACKNOWLEDGMENT}

We thank Claude Pierrepont for technical assistance.

\section{REFERENCES}

1. Beji, A., D. Izard, F. Gavini, H. Leclerc, M. Leseine-Delstanche, and J. Krembel. 1987. A rapid chemical procedure for isolation and purification of chromosomal DNA from Gram-negative bacilli. Anal. Biochem. 161:18-23.

2. Blazevic, D. J., M. H. Koepcke, and J. M. Matsen. 1973. Incidence and identification of Pseudomonas fluorescens and Pseudomonas putida in the clinical laboratory. Appl. Microbiol. 25:107-110.

3. Botzenhart, K., and H. Ruden. 1987. Hospital infections caused by Pseudomonas aeruginosa. Antibiot. Chemother. 39:1-15.

4. Bowman, J. P., L. I. Sly, A. C. Hayward, Y. Spiegel, and E. Stackebrandt 1993. Telluria mixta (Pseudomonas mixta Bowman, Sly, and Hayward 1988) gen. nov., comb. nov., and Telluria chitinolytica sp. nov., soil-dwelling organisms which actively degrade polysaccharides. Int. J. Syst. Bacteriol. 43:120124.

5. Champion, A. B., E. L. Barrett, N. J. Palleroni, R. L. Soderberg, R. Kunisawa, R. Contopoulou, A. C. Wilson, and M. Doudoroff. 1980. Evolution in Pseudomonas fluorescens. J. Gen. Microbiol. 120:485-511.

6. Coroler, L., M. Elomari, D. Izard, and H. Leclerc. 1996. Pseudomonas rhodesiae sp. nov., a new species isolated from natural mineral waters. Syst. Appl. Microbiol. 19:600-607.
7. Crosa, J. H., D. J. Brenner, and S. Falkow. 1973. Use of a single-strandspecific nuclease for analysis of bacterial and plasmid deoxyribonucleic acid homo- and heteroduplexes. J. Bacteriol. 115:904-911.

8. De Ley, J. 1970. Reexamination of the association between melting point, buoyant density, and chemical base composition of deoxyribonucleic acid. J. Bacteriol. 101:737-754.

9. De Ley, J., and J. Van Muylem. 1963. Some applications of deoxyribonucleic acid base composition in bacterial taxonomy. Antonie van Leeuwenhoek J. Microbiol. Serol. 29:344-358.

10. De Vos, D., A. Lim, P. De Vos, A. Sarniguet, K. Kersters, and P. Cornelis 1993. Detection of the outer membrane lipoprotein I and its gene in fluorescent and non-fluorescent pseudomonads: implications for taxonomy and diagnosis. J. Gen. Microbiol. 139:2215-2223.

11. De Vos, D., A. Van Landschoot, P. Segers, R. Tytgat, M. Gillis, M. Bauwens, R. Rossau, M. Goor, B. Pot, K. Kersters, P. Lizzaraga, and J. De Ley. 1989 Genotypic relationships and taxonomic localization of unclassified Pseudomonas and Pseudomonas-like strains by deoxyribonucleic acid-ribosomal ribonucleic acid hybridizations. Int. Syst. Bacteriol. 39:35-49.

12. De Vos, P., and J. De Ley. 1983. Intra- and intergeneric similarities of Pseudomonas and Xanthomonas ribosomal ribonucleic acid cistrons. Int. J. Syst. Bacteriol. 33:487-509.

13. De Vos, P., K. Kersters, E. Falsen, B. Pot, M. Gillis, P. Segers, and J. De Ley. 1985. Comamonas David and Park 1962 gen. nov., nom. rev. emend., and Comamonas terrigena Hugh 1962 sp. nov., nom. rev. Int. J. Syst. Bacteriol. 35:443-453.

14. Elomari, M., D. Izard, P. Vincent, L. Coroler, and H. Leclerc. 1994. Comparison of ribotyping analysis and numerical taxonomy studies of Pseudomonas putida biovar A. Syst. Appl. Microbiol. 17:361-369.

15. Elomari, M., L. Coroler, D. Izard, and H. Leclerc. 1995. A numerical taxonomic study of fluorescent Pseudomonas strains isolated from natural mineral waters. J. Appl. Bacteriol. 78:71-81.

16. Elomari, M., L. Coroler, D. Izard, and H. Leclerc. 1996. DNA relatedness among Pseudomonas strains isolated from natural mineral waters and proposal of Pseudomonas veronii sp. nov. Int. J. Syst. Bacteriol. 46:1138-1144.

17. Gardan, L., C. Bollet, M. Abu Ghorrah, F. Grimont, and P. A. D. Grimont. 1992. DNA relatedness among the pathovar strains of Pseudomonas syringae subsp. savastanoi Janse (1982) and proposal of Pseudomonas savastanoi sp. nov. Int. J. Syst. Bacteriol. 42:606-612.

18. Gilardi, G. L. 1972 . Infrequently encountered Pseudomonas species causing infections in humans. Ann. Intern. Med. 72:211-215.

19. Gilardi, G. L. 1973. Nonfermentative Gram-negative bacteria encountered in clinical specimens. Antonie van Leeuwenhoek J. Microbiol. Serol. 39:229242.

20. Grimont, P. A. D., M. Y. Popoff, F. Grimont, C. Coynault, and M. Lemelin 1980. Reproducibility and correlation study of three deoxyribonucleic acid hybridization procedures. Curr. Microbiol. 4:325-330.

21. Hayase, N., K. Taira, and K. Furukawa. 1990. Pseudomonas putida KF715 bphABCD operon encoding biphenyl and polychlorinated biphenyl degradation: cloning, analysis, and expression in soil bacterial. J. Bacteriol. 172:11601164.

22. Hugh, R., and G. L. Gilardi. 1980. Pseudomonas, p. 288-317. In E. H. Lennette, A. Balows, W. J. Hausler, and J. P. Truant (ed.), Manual of clinical microbiology, 3rd ed. American Society for Microbiology, Washington, D.C.

23. Jessen, O. 1965. Pseudomonas aeruginosa and other green fluorescent pseudomonads. A taxonomic study. Munksgaard, Copenhagen, Denmark.

24. Kasak, L., R. Hôrak, A. Nurk, K. Talvik, and M. Kivisaar. 1993. Regulation of the catechol 1,2-dioxygenase- and phenol monooxygenase-encoding pheBA operon in Pseudomonas putida. J. Bacteriol. 175:8038-8042.

25. King, E. O., M. K. Ward, and D. E. Raney. 1954. Two simple media for the demonstration of pyocyanin and fluorescein. J. Lab. Clin. Med. 44:301-307.

26. Leddy, M. B., D. W. Phipps, and H. F. Ridgway. 1995. Catabolite-mediated mutations in alternate toluene degradative pathways in Pseudomonas putida. J. Bacteriol. 177:4713-4720.

27. Love, N. G., and C. P. Leslie Grady. 1995. Impact of growth in benzoate and $m$-toluate liquid media on culturability of Pseudomonas putida on benzoate and $m$-toluate plates. Appl. Environ. Microbiol. 61:3142-3144.

28. Marmur, J. 1961. A procedure for the isolation of deoxyribonucleic acid from microorganisms. J. Mol. Biol. 3:208-218.

29. Marmur, J., and P. Doty. 1962. Determination of the base composition of deoxyribonucleic acid from its thermal denaturation temperature. J. Mol. Biol. 5:109-118.

30. Molin, G., and A. Ternström. 1982. Numerical taxonomy of the psychrotrophic pseudomonads. J. Gen. Microbiol. 128:1249-1264.

31. O'Connor, K., C. M. Buckley, S. Hartmans, and A. D. W. Dobson. 1995. Possible regulatory role for nonaromatic carbon sources in styrene degradation by Pseudomonas putida CA-3. Appl. Environ. Microbiol. 61:544-548.

32. Palleroni, N. J. 1984. Genus I. Pseudomonas Migula 1894, $237^{\text {AL }}$ (n. m. cons. opin. 5, jud. comm. 1952, 237), p. 141-199. In N. R. Krieg and J. G. Holt (ed.), Bergey's manual of systematic bacteriology, vol. 1. The Williams and Wilkins Co., Baltimore, Md.

33. Palleroni, N. J. 1992. Human- and animal-pathogenic pseudomonads, p. 3086-3103. In A. Balows, H. G. Trüper, M. Dworkin, W. Harder, and K. H. 
Schleifer (ed.), The prokaryotes. A handbook on the biology of bacteria: ecophysiology, isolation, identification, applications, vol. 3. Springer-Verlag, New York, N.Y.

34. Palleroni, N. J. 1992. Introduction to the family Pseudomonadaceae, p 3071-3085. In A. Balows, H. G. Trüper, M. Dworkin, W. Harder, and K. H Schleifer (ed.), The prokaryotes. A handbook on the biology of bacteria: ecophysiology, isolation, identification, applications, vol. 3. Springer-Verlag, New York, N.Y.

35. Palleroni, N. J. 1992. Present situation of the taxonomy of pseudomonads, p. 105-115. In E. Galli, S. Silver, and B. Witholt (ed.), Pseudomonas: molecular biology and biotechnology. American Society for Microbiology, Washington, D.C.

36. Palleroni, N. J., and J. F. Bradbury. 1993. Stenotrophomonas, a new bacterial genus for Xanthomonas maltophilia (Hugh 1980) Swings et al. 1983. Int. J. Syst. Bacteriol. 43:606-609.

37. Palleroni, N. J., M. Doudoroff, R. Y. Stanier, R. E. Solanes, and M. Mandel 1970. Taxonomy of the aerobic pseudomonads: the properties of the Pseudomonas stutzeri group. J. Gen. Microbiol. 60:215-231.

38. Palleroni, N. J., R. Kunisawa, R. Contopoulou, and M. Doudoroff. 1973 Nucleic acid homologies in the genus Pseudomonas. Int. J. Syst. Bacteriol. 23:333-339.

39. Palleroni, N. J., R. W. Ballard, R. Ralston, and M. Doudoroff. 1972. Deoxyribonucleic acid homologies among some Pseudomonas species. J. Bacteriol. 110:1-11.

40. Parales, R. E., and C. S. Harwood. 1993. Regulation of the pcaIJ genes for aromatic acid degradation in Pseudomonas putida. J. Bacteriol. 175:58295838.

41. Pedersen, M. M., E. Marso, and M. J. Pickett. 1970. Non-fermentative bacilli associated with man. III. Pathogenicity and antibiotic susceptibility. Am. J. Clin. Pathol. 54:178-192.

42. Ralston-Barrett, E., N. J. Palleroni, and M. Doudoroff. 1976. Phenotypic characterization and deoxyribonucleic acid homologies of the "Pseudomonas alcaligenes" group. Int. J. Syst. Bacteriol. 26:421-426.

43. Rogers, K. B. 1960. Pseudomonas infections in a children's hospital. J. Appl. Bacteriol. 23:533-537.

44. Saint-Onge, A., F. Romeyer, P. Lebel, L. Masson, and R. Brousseau. 1992 Specificity of the Pseudomonas PAO1 lipoprotein I gene as a DNA probe and PCR target region within the Pseudomonadaceae. J. Gen. Microbiol 138:733-741.

45. Sambrook, J., E. F. Fritsch, and T. Maniatis. 1989. Molecular cloning: laboratory manual, 2nd ed. Cold Spring Harbor Laboratory Press, Cold Spring Harbor, N.Y.

46. Schwartz, A., and R. Bar. 1995. Cyclodextrin-enhanced degradation of toluene and $p$-tolouic acid by Pseudomonas putida. Appl. Environ. Microbiol. 61:2727-2731.

47. Segers, P., M. Vancanneyt, B. Pot, U. Torck, B. Hoste, D. Dewettinck, E Falsen, K. Kersters, and P. De Vos. 1994. Classification of Pseudomonas diminuta Leifson and Hugh 1954 and Pseudomonas vesicularis Büsing, Döll, and Freytag 1953 in Brevundimonas gen. nov. as Brevundimonas diminuta comb. nov. and Brevundimonas vesicularis comb. nov., respectively. Int. J. Syst. Bacteriol. 44:499-510.

48. Shen, H., and Y. Wang. 1995. Simultaneous chromium reduction and phenol degradation in a coculture of Escherichia coli ATCC 33456 and Pseudomonas putida DMP-1. Appl. Environ. Microbiol. 61:2754-2758.

49. Stackebrandt, E., and B. M. Goebel. 1994. Taxonomic note: a place for DNA-DNA reassociation and 16S rRNA sequence analysis in the present species definition in bacteriology. Int. J. Syst. Bacteriol. 44:846-849.

50. Stackebrandt, E., and W. Liesack. 1993. Nucleic acids and classification, p.
151-194. In M. Goodfellow and A. G. O'Donnell (ed.), Handbook of new bacterial systematics. Academic Press, Ltd., London, United Kingdom.

51. Stanier, R. Y., N. J. Palleroni, and M. Doudoroff. 1966. The aerobic pseudomonads: a taxonomic study. J. Gen. Microbiol. 43:159-271.

52. Sutter, V. 1968. Identification of Pseudomonas species isolated from hospital environment and human species. Appl. Microbiol. 16:1532-1538.

53. Swings, J. P. De Vos, M. Van Den Mooter, and J. De Ley. 1983. Transfer of Pseudomonas maltophilia Hugh 1981 to the genus Xanthomonas as Xanthomonas maltophilia (Hugh 1981) comb. nov. Int. J. Syst. Bacteriol. 33:409 413.

54. Tamaoka, J., D. M. Ha, and K. Komagata. 1987. Reclassification of Pseudomonas acidovorans den Dooren de Jong 1926 and Pseudomonas testosteron Marcus and Talalay 1956 as Comamonas acidovorans comb. nov. and Comamonas testosteroni comb. nov., with an emended description of the genus Comamonas. Int. J. Syst. Bacteriol. 37:52-59.

55. Vandamme, P., B. Pot, M. Gillis, P. De Vos, K. Kersters, and J. Swings. 1996 Polyphasic taxonomy, a consensus approach to bacterial systematics. Microbiol. Rev. 60:407-438.

56. Van Niel, C. B., and M. B. Allen. 1952. A note on Pseudomonas stutzeri J. Bacteriol. 64:413-422.

57. Von Graevenitz, A. 1985. Ecology, clinical significance and antimicrobia susceptibility of infrequently encountered glucose nonfermenting Gram negative rods, p. 181-232. In G. L. Gilardi (ed.), Nonfermentative Gram negative rods. Marcel Dekker, New York, N.Y.

58. Von Graevenitz, A., and J. Weinstein. 1971. Pathogenic significance of Pseudomonas fiuorescens and Pseudomonas putida. Yale J. Biol. Med. 43: 265-272.

59. Willems, A., E. Falsen, B. Pot, E. Jantzen, B. Hoste, P. Vandamme, M. Gillis, K. Kersters, and J. De Ley. 1990. Acidovorax, a new genus for Pseudomonas facilis, Pseudomonas delafieldii, EF group 13, EF group 16, and several clinical isolates, with the species Acidovorax facilis comb. nov., Acidovorax delafieldii comb. nov., and Acidovorax temperans sp. nov. Int. J. Syst. Bacteriol. 40:384-398.

60. Willems, A., J. Busse, M. Goor, B. Pot, E. Falsen, E. Jantzen, B. Hoste, M. Gillis, K. Kersters, G. Auling, and J. De Ley. 1989. Hydrogenophaga, a new genus of hydrogen-oxidizing bacteria that includes Hydrogenophaga flava comb. nov. (formerly Pseudomonas flava), Hydrogenophaga palleronii (formerly Pseudomonas palleronii), Hydrogenophaga pseudoflava (formerly Pseudomonas pseudoflava and "Pseudomonas carboxydoflava"), and Hydrogenophaga taeniospiralis (formerly Pseudomonas taeniospiralis). Int. J. Syst. Bacteriol. 39:319-333.

61. Woese, C. R. 1987. Bacterial evolution. Microbiol. Rev. 51:221-271.

62. Yabuuchi, E., I. Yano, H. Oyaizu, Y. Hashimoto, T. Ezaki, and H. Yamamoto. 1990. Proposals of Sphingomonas paucimobilis gen. nov. and comb. nov., Sphingomonas parapaucimobilis sp. nov., Sphingomonas yanoikuyae sp. nov., Sphingomonas adhaesiva sp. nov., Sphingomonas capsulata comb. nov., and two genospecies of the genus Sphingomonas. Microbiol. Immunol. 34: 99-119.

63. Yabuuchi, E., Y. Kosako, H. Oyaizu, I. Yano, H. Hotta, and Y. Nishiuchi. 1995. Transfer of two Burkholderia and an Alcaligenes species to Ralstonia gen. nov.: proposal of Ralstonia pickettii (Ralston, Palleroni and Doudorof 1973) comb. nov., Ralstonia solanacearum (Smith 1896) comb. nov. and Ralstonia eutropha (Davis 1969) comb nov. Microbiol. Immunol. 39:897-904.

64. Yabuuchi, E., Y. Kosako, H. Oyaizu, I. Yano, H. Hotta, Y. Hashimoto, T. Ezaki, and M. Arakawa. 1992. Proposal of Burkholderia gen. nov. and transfer of seven species of the genus Pseudomonas homology group II to the new genus, with the type species Burkholderia cepacia (Palleroni and Holmes 1981) comb. nov. Microbiol. Immunol. 36:1251-1275. 